\title{
Twórcy szkoleń bibliotecznych on-line w polskich bibliotekach uczelnianych
}

\section{Wprowadzenie}

System edukacji, podobnie jak każda dziedzina życia, nie pozostaje obojętny na zmiany technologiczne. Ogromne zasoby informacji powszechnie dostępne w sieci, nieuporządkowane i nieustrukturyzowane, powodują, że nauczyciel jako źródło unikatowej wiedzy należy już do przeszłości, a jego nową misją staje się m.in. pełnienie roli przewodnika po nieprzebranych źródłach informacji elektronicznej oraz ich strukturyzacja ${ }^{1}$. Jakościowym zmianom podlega także sam system kształcenia. Powstają bowiem nowe platformy edukacyjne, zmieniające tradycyjne sposoby przyswajania wiedzy przez uczniów czy studentów, umożliwiające naukę wszędzie tam, gdzie jest dostępny Internet, bez względu na ograniczenia czasowe i przestrzenne. $W$ tej sytuacji nie dziwi więc fakt, że coraz częściej istotnym elementem procesu edukacji stają się e-learningowe formy kształcenia.

Według Marka Hyli, „e-learning to wszelkie działania wspierające proces szkolenia, wykorzystujące technologie teleinformatyczne"2. Popularny na zachodzie Europy, w Stanach Zjednoczonych i Japonii, coraz po-

1 R. R. Gajewski, Projekt EllaStan: e-samokształcenie potencjalnych telepracowników, [w:] E-edukacja.net: materiały z III ogólnopolskiej konferencji: Rozwój e-edukacji w ekonomicznym szkolnictwie wyższym, pod red. M. Dąbrowskiego i M. Zająca, Warszawa 2007, s. 15.

2 M. Hyla, Przewodnik po e-learningu, Kraków 2005, s. 19. 
wszechniej wkracza również do polskiego systemu edukacji, w tym - do bibliotek różnych typów szkół wyższych, m.in. bibliotek uniwersyteckich, akademii medycznych czy szkół wyższych niepublicznych. Przejawem tych przeobrażeń na gruncie polskim jest choćby pojawienie się oferty szkoleń on-line przeznaczonych specjalnie dla bibliotekarzy w postaci funkcjonującego od 2002 r. internetowego kursu „Bibweb”. Coraz więcej mówi się także o zaletach e-learningu w kontekście funkcjonowania bibliotek i kształcenia ich pracowników.

Nieco mniej uwagi poświęca się z kolei bibliotekarzom, którzy tworzą i prowadzą szkolenia biblioteczne on-line. W praktyce, aby zorganizować takie szkolenie, muszą oni mieć odpowiednie doświadczenie, wiedzę i określone umiejętności. Podczas przygotowań należy bowiem właściwie zdefiniować odbiorcę szkolenia i odpowiednio rozeznać jego potrzeby, zaplanować budżet, umiejscowić szkolenie w czasie, wybrać sposób oceny efektywności procesów szkoleniowych (np. test, ankieta), a także określić narzędzia edukacyjne i technologiczne (np. platformę Moodle, programy PowerPoint, Flash) oraz zaprojektować sam program szkolenia. Następnie należy opracować taki materiał multimedialny, z którego każda osoba będzie mogła korzystać zgodnie z własnymi preferencjami i zdolnościami percepcyjnymi ${ }^{3}$, a który jednocześnie będzie zachęcał do angażowania się $\mathrm{w}$ proces nauczania. Na etapie przygotowywania materiału edukacyjnego kluczowa wydaje się jednak nie tylko jakość merytoryczna materiałów, ale także ich wartość metodyczna oraz opracowanie graficzne, uwzględniające w sposób wyważony elementy multimedialne. Szkolenie należy przetestować, zapoznać z nim pracowników biblioteki i wreszcie uruchomić je w Internecie, zapewniając odpowiednią informację dla szkolących się. Dalszy etap to ciągła komunikacja między nauczycielem i administratorem a studentami w celu rozwiązywania problemów natury merytorycznej i technicznej. Ostatni etap - to ocena szkolenia na podstawie ankiet wypełnianych przez jego użytkowników bądź pośrednio poprzez analizę wyników testu.

Jak widać, podczas organizacji szkolenia potrzebne są rozległe oprócz merytorycznych - umiejętności planowania, budżetowania, komunikacji (e-contact) z uczącymi się, administracji i zarządzania procesem dydaktycznym. Ponadto przydatne są także zdolności redakcyjne, metodyczne i informatyczne, konieczne do przetworzenia treści mery-

3 Tamże, s. 168. 
torycznych na materiały edukacyjne (e-content $)^{4}$. Niezbędna wydaje się również umiejętność pracy w zespole - najpierw należy go stworzyć, a następnie we współpracy z innymi wykonać szkolenie w określonym czasie w ramach zaplanowanego budżetu.

Jak w świetle tych wymagań prezentują się bibliotekarze zajmujący się szkoleniami on-line w polskich bibliotekach w szerokim tego słowa znaczeniu - od ich twórców aż po administratorów i prowadzących? W pewnej mierze odpowiedzi na to pytanie mogą dostarczyć zaprezentowane $\mathrm{w}$ niniejszym artykule wyniki badań. Ich autorkę interesowało, kto jest inicjatorem bibliotecznych szkoleń on-line, kto się nimi zajmuje - jakie doświadczenie, wykształcenie, kwalifikacje mają te osoby, jakie zadania pełnią w bibliotekach oraz jaka jest ich opinia na temat tej nowej formy kształcenia.

\section{Autorskie badania ankietowe}

Dy móc w pełni scharakteryzować twórców polskich szkoleń biblioB tecznych, skonstruowano kwestionariusz ankiety, złożony z 17 pytań (w przewadze jednokrotnego wyboru) i metryczki. Ankietę w wersji elektronicznej rozesłano w kwietniu 2009 r. do 38 bibliotek, które na swoich stronach informowały o prowadzeniu szkoleń on-line lub zamieściły wirtualne przewodniki biblioteczne, mogące stanowić materiał dydaktyczny do tego typu szkoleń (pozwalało to przypuszczać, że wprowadziły one nauczanie na odległość). Do dnia 6 maja 2009 r. wypełnione ankiety odesłało 31 pracowników z 18 bibliotek, reprezentujących następujące typy placówek:

- uniwersyteckie (5),

- akademii (4, w tym 3 medyczne),

- politechnik (1),

- państwowych wyższych szkół zawodowych (1),

- niepublicznych szkół wyższych (7).

Ponadto z 6 bibliotek otrzymano odpowiedź, że nie prowadziły one i nie prowadzą szkoleń on-line (jedna z nich ma zamiar wprowadzić takie szkolenia dopiero w roku akademickim 2009/2010). Ponieważ 14 z wytypowanych do badań bibliotek nie odpowiedziało na ankietę, nie udało

${ }^{4}$ R. R. Gajewski, dz. cyt., s. 117. 
się zweryfikować, czy mimo sugerowanej w Internecie informacji o organizacji tego typu szkoleń w placówkach tych w ogóle się je prowadzi.

Biorąc pod uwagę liczbę placówek, z których otrzymano ankiety, można stwierdzić, że poziom ich zwrotności był dość wysoki. Z uwagi na to, że nie wszyscy bibliotekarze zajmujący się szkoleniami on-line w danej placówce odesłali wypełnione ankiety, otrzymane informacje należy traktować jako niepełne. Zebrany materiał wydaje się jednak na tyle interesujący, że warto pokusić się o jego analizę oraz sformułowanie kilku ogólnych wniosków.

Aby móc stworzyć biblioteczne szkolenie e-learningowe, odpowiadające na rzeczywiste zapotrzebowanie odbiorców i atrakcyjne dla nich, potrzebne jest m.in. doświadczenie czerpane z uczestnictwa w podobnych inicjatywach i z pracy z odbiorcą usług bibliotecznych, a ściślej - dogłębna znajomość jego potrzeb. Czy ankietowani bibliotekarze spełniali te warunki? Okazuje się, że wśród respondentów przeważały osoby ze sporym doświadczeniem zawodowym ( 9 spośród 29 osób, które odpowiedziały na pytanie, posiadało staż pracy w bibliotece 6-10 lat, 12 osób - więcej niż 11 lat, tylko 8 osób mniej niż 5 lat). W większości placówek byli to starsi bibliotekarze i kustosze (18), rzadziej - młodsi bibliotekarze i bibliotekarze (9 osób). Szkoleniami zajmowali się także bibliotekarze dyplomowani (4 osoby). W grupie 9 kustoszy aż 7 zaangażowało się w przygotowanie szkoleń z zakresu podstaw informacji naukowej bądź zawierających jej elementy. Typy stanowisk najczęściej zajmowanych przez bibliotekarzy prowadzących szkolenia on-line prezentuje wykres 1.

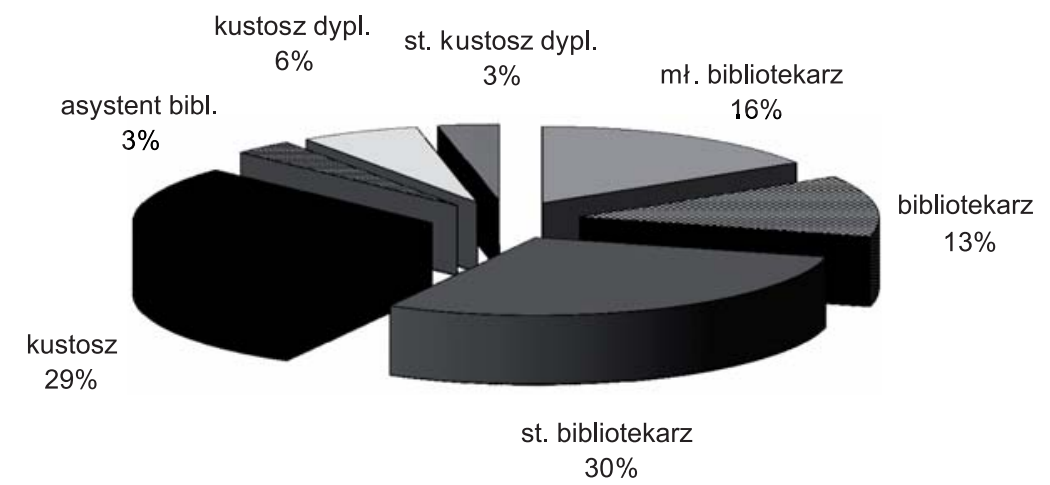

Wykres 1. Stanowiska zajmowane przez bibliotekarzy prowadzących szkolenia on-line

Źródło: opracowanie własne. 
Wyniki badań wskazują, że o ile ankietowani bibliotekarze posiadali duże doświadczenie w zakresie prowadzenia tradycyjnych szkoleń - na 31 osób tylko jedna nie prowadziła tego typu zajęć, o tyle nie mieli oni już zbyt wielu doświadczeń związanych z e-learningiem - w tę formę kształcenia zaangażowało się jedynie 9 osób. Ciekawostką jest, że tylko 1 osoba skorzystała z oferty „Bibweba”, 2 brały udział w kursach z zakresu podstaw e-learningu, a pozostałe uczestniczyły w szkoleniach poświęconych tematyce ekonomicznej bądź bazom danych.

Wsparcie informatyków podczas tworzenia szkoleń okazało się niezbędne (por. wykres 2). Z reguły opiekę informatyczną nad szkoleniem sprawowali informatycy - zatrudnieni w bibliotece ( 6 bibliotek) lub pochodzący spoza niej (8 bibliotek). Tylko w trzech przypadkach (1 biblioteka uniwersytecka, 1 politechniki i 1 niepublicznej szkoły wyższej) przygotowanie informatycznej strony szkolenia było dziełem wyłącznie bibliotekarzy.

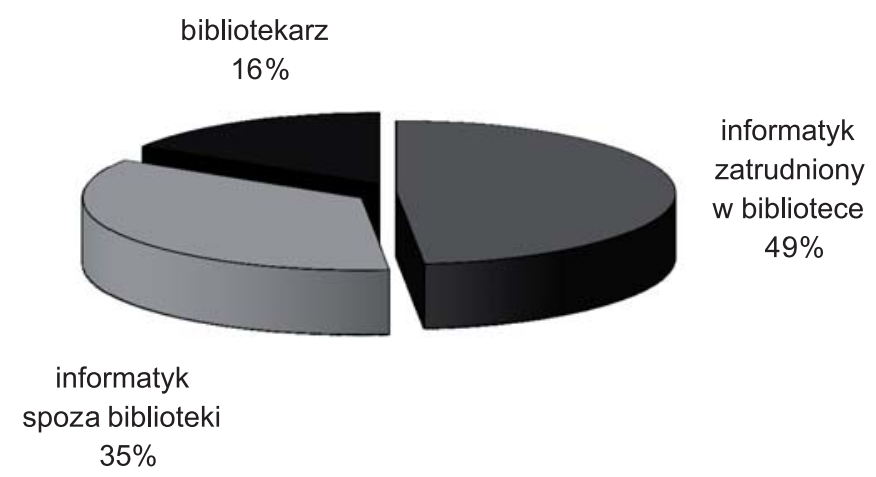

Wykres 2. Autorzy informatycznego opracowania szkoleń bibliotecznych on-line Źródło: opracowanie własne.

Połowa ankietowanych (15 na 30 osób, które udzieliły odpowiedzi na to pytanie) podwyższała swoje kwalifikacje potrzebne do pracy nad szkoleniami on-line. Najczęściej dokształcali się pracownicy bibliotek akademii medycznych (7 z 11 osób), najrzadziej - uniwersytetów (2 z 9). W pozostałych typach bibliotek nie zauważono już takich dysproporcji. Wśród najczęstszych form dokształcania bibliotekarze wymieniali: konsultacje (5), samokształcenie (4) i szkolenia (4). Spośród tych osób 13 wymieniło zakres dokształcania się: administrowanie platformą, grafika, CMS itp. 
Zgromadzony materiał dowodzi, że bibliotekarze organizowali różne typy szkoleń bibliotecznych. W 2 bibliotekach akademii medycznych przeprowadzono szkolenia $\mathrm{z}$ podstaw informacji naukowej. $\mathrm{W}$ jednej z nich przygotowano dodatkowo także kurs z zakresu informacji medycznej. Szkolenia z elementami informacji naukowej odbywały się w 4 bibliotekach uniwersyteckich oraz 3 bibliotekach niepublicznych szkół wyższych, a szkolenia on-line dla studentów pierwszego roku studiów - we wszystkich typach placówek.

Organizacją szkoleń on-line zajmowali się bibliotekarze pełniący różne funkcje i pracujący w różnych działach bibliotek. Wśród najczęstszych reprezentantów byli wymieniani pracownicy oddziałów informacji naukowej (12 razy). Mniej licznie angażowali się przedstawiciele sekcji czasopism i baz oraz gromadzenia, opracowania i udostępniania zbiorów (2 razy) czy wreszcie działów bibliograficznego, informatyzacji, digitalizacji, zbiorów specjalnych, udostępniania (po 1 wystąpieniu). Uruchomieniem szkoleń były również zainteresowane osoby pełniące funkcje zarządcze i kierownicze (10 osób). To właśnie szefowie bibliotek należeli do najczęstszych inicjatorów szkoleń on-line. Miało to miejsce w 3 bibliotekach akademii medycznych, 3 bibliotekach uniwersyteckich, 1 bibliotece politechniki, 1 bibliotece państwowej wyższej szkoły zawodowej i 1 bibliotece uczelni niepaństwowej (razem 9 bibliotek). W 2 bibliotekach szkolenia takie wprowadzono na życzenie władz uczelnianych, a w jednej jako efekt współpracy bibliotekarzy ze Studium E-learningu. W pozostałych 6 placówkach inicjatywa ta należała do pracowników bibliotek.

Z zebranych danych wynika, że w większości bibliotek nad organizacją szkoleń pracowały nieduże, tj. 3-4-osobowe zespoły. Jedynie w jednej bibliotece akademii medycznej w proces ten zaangażowało się 8-10 osób. W czterech bibliotekach opracowywanie programu szkoleń powierzono jednej osobie. Wydaje się, że podział zadań w zespołach miał charakter umowny - przeważnie bibliotekarze zajmowali się wszystkimi etapami organizacji szkolenia, tj. od prac koncepcyjnych i merytorycznych, po opracowanie graficzne i administrowanie szkoleniem (12 bibliotekarzy). Najbardziej pracochłonne było przygotowanie merytoryczne (na tym polu pracowało 30 bibliotekarzy) oraz koncepcyjne szkolenia (22 bibliotekarzy). Opracowaniem graficznym kursów zajmowało się 17 osób, a ich administrowaniem - 18.

Część osób (20) przygotowujących szkolenia pełniła także rolę nauczycieli. W dużych bibliotekach byli to najczęściej pracownicy oddzia- 
łów informacji naukowej (11 osób) - wyjątek stanowił jeden dyrektor, w mniejszych zaś - osoby pełniące funkcje zarządcze i kierownicze (5), zajmujące się informacją naukową, bibliotekami cyfrowymi bądź udostępnianiem zbiorów (po 1 osobie). Rola tzw. e-nauczyciela polegała przede wszystkim na udzielaniu doraźnej pomocy użytkownikom (19 osób). 6 osób z 3 bibliotek (biblioteka uniwersytecka, biblioteka akademii medycznej i państwowej wyższej szkoły zawodowej) łączyło taki sposób prowadzenia szkoleń z opieką nad małą grupą studentów lub pojedynczym studentem. Tylko w jednej bibliotece (uczelni niepublicznej) nauczyciel pełnił rolę e-tutora dla małej grupy studentów.

Ponad połowa osób (18 z 31) prace nad szkoleniami on-line prowadziła w ramach powierzonych obowiązków służbowych. Dwie z tych osób (z dwóch bibliotek akademii medycznych) zostały za tę pracę dodatkowo wynagrodzone. Pozostałe zajmowały się szkoleniami poza swymi obowiązkami - z tych osób tylko pracownicy jednej biblioteki akademii medycznej zostali premiowani dodatkowym wynagrodzeniem lub nagrodą.

Badania dowiodły ogólnie pozytywnej oceny szkoleń on-line wśród ich twórców. 25 osób przyznało, że bez wątpienia usprawniły one pracę biblioteki. Co do skuteczności tej formy kształcenia zdania były jednak podzielone. 15 osób stwierdziło, że zwiększyły one wiedzę studentów bardziej niż szkolenia tradycyjne, a 4 uznały, że są one mniej skuteczne od tradycyjnych. Ankietowani przyznali, że dzięki szkoleniom bibliotecznym on-line biblioteka zyskała na prestiżu szczególnie wśród studentów (18 osób), mniej - gdy chodzi o władze uczelni (tylko 9 osób). Aż 28 osób (na 30 odpowiedzi) stwierdziło, że praca nad szkoleniami on-line sprawiła im satysfakcję. Opinie bibliotekarzy na temat skuteczności i oddziaływania szkoleń on-line na środowisko lokalne prezentuje wykres 3.

Analizując dane demograficzne respondentów, warto zauważyć, że większość wśród osób zajmujących się szkoleniami on-line w bibliotekach stanowiły kobiety (27 osób). Jeśli chodzi o wiek, to były to przede wszystkim osoby między 31 a 55 rokiem życia (19 na 28 osób, które podały swój wiek). Wszyscy ankietowani bibliotekarze posiadali wykształcenie wyższe: 13 osób ukończyło informację naukową i bibliotekoznawstwo, 4 - kierunki ze specjalnością pokrewną, pozostałe - kierunki związane głównie z profilem uczelni (osoby te najczęściej legitymowały się także dyplomem ukończenia studiów podyplomowych z zakresu bibliologii). 


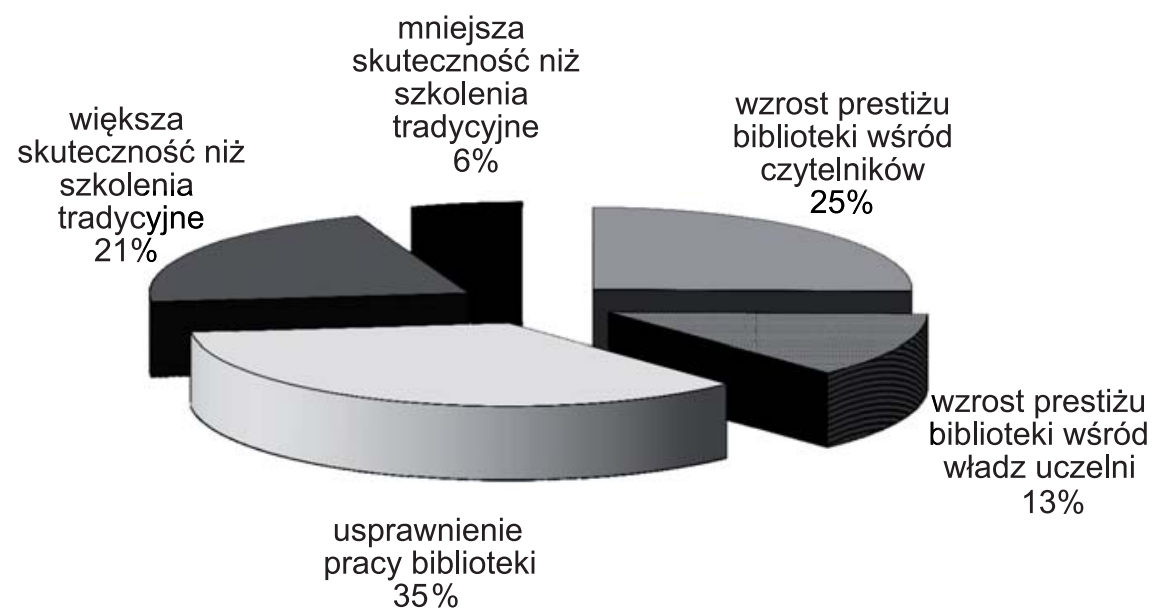

Wykres 3. Opinie bibliotekarzy na temat skuteczności i oddziaływania szkoleń bibliotecznych on-line

Źródło: opracowanie własne.

\section{Podsumowanie}

Drzeprowadzone badania dowodzą silnego przekonania kadry zarządzającej bibliotekami o celowości wprowadzania szkoleń on-line do dydaktyki bibliotecznej. Mimo że opinia ta jest widoczna również wśród samych bibliotekarzy, którzy dość często sami inicjują tego typu formy kształcenia użytkowników, to zdarza się, że zadanie to jest przez nich przyjmowane jako dodatkowy obowiązek. Niestety, przyjęcie na siebie ciężaru tworzenia i prowadzenia szkoleń nie wiąże się ani z przyznaniem dodatkowego wynagrodzenia, ani zmniejszeniem zakresu dotychczas wykonywanych czynności. Wprowadzenie e-learningu do bibliotek nie przyczynia się - zdaniem ankietowanych bibliotekarzy - także do zmiany wizerunku tych placówek w oczach władz uczelni. Być może przeobrażenia bibliotek nie są już postrzegane jako nowość, a jedynie jako konsekwencja ich systematycznej informatyzacji. A może przekonanie bibliotekarzy o negatywnej opinii decydentów na temat bibliotek to tylko efekt rozgoryczenia z powodu braku gratyfikacji za ich dodatkową pracę?

Zebrany materiał ankietowy udowadnia, że bibliotekarze preferują przede wszystkim pracę zespołową, co przy tworzeniu projektów 
e-learningowych jest właściwie wymogiem. Choć na razie niewielu pracowników bibliotek potrafi jeszcze łączyć wiedzę z umiejętnościami informatycznymi, pocieszający jest stale rosnący udział bibliotekarzy w różnego typu formach kształcenia prowadzonych w zakresie obsługi platform e-learningowych i innych narzędzi informatycznych, podejmowany z zamiarem samodzielnego prowadzenia (być może i tworzenia) szkoleń on-line.

Niestety, nadal niewielkie jest osobiste doświadczenie bibliotekarzy w zakresie e-learningu. Z grupy badanych wyróżniają się pracownicy akademii medycznych, którzy jako jedyni podjęli prace nad szkoleniami on-line dla wyspecjalizowanego odbiorcy. Bibliotekarze ci nie tylko pracowali w większych niż przeciętnie zespołach (we współpracy z informatykami), ale także częściej niż inni dokształcali się, przez co zasłużyli na uznanie w opinii władz uczelni, a co za tym idzie na dodatkowe wynagrodzenie.

Wyniki ankiet dostarczają także kilku spostrzeżeń na temat roli e-nauczyciela w bibliotece ${ }^{5}$. Wydaje się, że dla bibliotekarzy jest to dopiero początek nowej drogi. Spora część ankietowanych (20 na 31) zdecydowała się już na wypełnienie misji bycia przewodnikiem łączącym umiejętności dydaktyczne i informatyczne z wiedzą merytoryczną. Wyzwanie to podjęli przede wszystkim pracownicy doświadczeni w zakresie dydaktyki bibliotecznej, najczęściej z oddziałów informacji naukowej, oraz szefowie mniejszych bibliotek. Niestety, wśród nich brakowało prawdziwych e-tutorów, którzy nie sprowadzaliby formy pracy z użytkownikiem jedynie do udzielenia mu doraźnej pomocy (w przypadku zaistnienia konkretnej potrzeby informacyjnej czy pojawienia się problemu). Tymczasem, jak pokazują przykładowe badania uczestników szkoleń e-learningowych ${ }^{6}$, ich oczekiwania wobec e-nauczyciela koncentrują się głównie na indywidualnym podejściu do ucznia czy studenta, budowaniu z nim więzi, życzliwości, dostępności i dyspozycyjności, a dopiero potem

${ }^{5}$ Więcej o roli e-nauczyciela w bibliotekach (net-bibliotekarza) zob. A. Śniechowska-Karpińska, E-learning jako jedna z metod edukacji użytkowników bibliotek naukowych i bibliotekarzy oraz element promocji biblioteki. W: Kształcenie użytkowników naukowej informacji medycznej - koncepcje i doświadczenia, Lublin-Kazimierz Dolny, 12-14 czerwca 2006 r. [on-line]. [Warszawa] 2006 (EBIB Materiały konferencyjne; nr 14) [dostęp 15 lipca 2009]. Dostępny w World Wide Web: http://www.ebib.info/publikacje/matkonf/25kpbm/sniechowska2.php.

${ }^{6}$ Mowa tu o badaniach przeprowadzonych w lutym 2004 r. na studentach Wyższej Szkoły Humanistyczno-Ekonomicznej w Łodzi, realizujących studia na platformie Polskiego Uniwersytetu Wirtualnego. Cyt. za: D. Kwiatkowska, Nauczyciel wspierający rozwój, [w:] Akademia on-line, pod red. J. Mischke, Łódź 2005, s. 139-147. 
na umiejętnym przekazywaniu posiadanej wiedzy. Trudno jednak wymagać od bibliotekarzy, którzy niejednokrotnie tworzą szkolenia z własnej inicjatywy, mając do dyspozycji skromny budżet, takiej indywidualizacji szkoleń, jaką są w stanie zapewnić np. firmy e-learningowe. Oferują one szkolącym się nie tylko indywidualną opiekę e-tutorów, ale także dostosowanie form nauczania do stylu uczenia i nabywania umiejętności reprezentowanego przez uczestnika szkolenia (wzrokowiec, słuchowiec, kinestetyk) ${ }^{7}$. Jak dowodzą choćby przeprowadzone badania i mimo pewnych niedoskonałości, e-learning to bez wątpienia dobra droga dla bibliotekarzy. Droga, która wiąże się z rozwojem zawodowym oraz zmianą wizerunku samego bibliotekarza. Zmianę tę dostrzegli już ankietowani, wskazując na wzrost prestiżu biblioteki w oczach jej czytelników. Czytelników, bez których obecności przecież nawet najlepiej wyposażona biblioteka jest martwa.

\section{Załącznik $^{8}$}

\section{Wykaz szkoleń on-line prowadzonych przez polskie biblioteki uczelniane [stan na dzień 15 lipca 2009 r.]}

1. Biblioteka Akademii Medycznej w Gdańsku, „Szkolenie on-line”: http:// www.biblioteka.amg.gda.pl/szkolenie/.

2. Biblioteka Akademii Medycznej we Wrocławiu, „Szkolenie on-line”: http://www.bg.am.wroc.pl/szkolenie/.

3. Biblioteka Główna Akademii Ekonomicznej w Katowicach, „Informacje o bibliotece": http://www.bg.ae.katowice.pl/content/view/26/37/.

4. Biblioteka Główna Akademii Podlaskiej, „Wirtualna prezentacja po bibliotece": http://www.bg.ap.siedlce.pl/szkolenie_www/index_content. html.

5. Biblioteka Główna Politechniki Białostockiej, „Informator dla studentów I roku": http://biblioteka.pb.edu.pl/?id=informator_I_roku.

${ }^{7}$ R. Kupczyk, Wpływ e-learningu na konkurencyjność gospodarki opartej na wiedzy, [w:] W. Bokajło, A. Wiktorska-Święcka, Edukacja w Polsce wobec wyzwań konkurencyjności Unii Europejskiej, Wrocław 2008, s. 130.

${ }^{8}$ Wykaz przygotowano na podstawie: A. Żurowska, Szkolenia on-line w polskich bibliotekach. Biuletyn EBIB [on-line] 2009, nr 4 (104) [dostęp 15 lipca 2009]. Dostępny w World Wide Web: http://www.ebib.info/2009/104/a.php?linki. 
6. Biblioteka Główna Uniwersytetu Ekonomicznego we Wrocławiu, „Elektroniczny informator": http://www.bg.ae.wroc.pl/images/stories//informator2009calosc.pdf.

7. Biblioteka Katolickiego Uniwersytetu Lubelskiego, „Szkolenie biblioteczne on-line": http://www.kul.lublin.pl/11873.html.

8. Biblioteka Medyczna Collegium Medicum w Bydgoszczy, „Przewodnik po bibliotece": http://biblio.cm.umk.pl/index.php?id=83.

9. Biblioteka Państwowej Wyższej Szkoły Zawodowej w Lesznie, „Informator czytelnika": http://www.biblioteka.pwsz.edu.pl/page.php?mn=8\&p=8.

10. Biblioteka Państwowej Wyższej Szkoły Zawodowej w Nysie, „Szkolenie on-line": http://biblioteka.pwsz.nysa.pl/szkolenie_biblioteczne.html.

11. Biblioteka Politechniki Koszalińskiej, ,Szkolenie biblioteczne”: http://biblioteka.tu.koszalin.pl/szkolenie_biblioteczne.htm.

12. Biblioteka Politechniki Krakowskiej, „Prezentacja biblioteki”: http:// www.biblos.pk.edu.pl/files/File/prezentacja_BPK.ppt.

13. Biblioteka Politechniki Lubelskiej, „Szkolenie biblioteczne”: http://bib. pollub.pl/index1280.html.

14. Biblioteka Politechniki Poznańskiej, Kurs „Usługi biblioteczno-informacyjne" na platformie e-learningowej: http://150.254.171.228/moodle/.

15. Biblioteka Politechniki Śląskiej, „Przewodnik po bibliotece”: http:// www.bg.polsl.pl/strony/przewodnik.ppt.

16. Biblioteka Pomorskiej Akademii Medycznej w Szczecinie, „Szkolenie biblioteczne on-line": http://212.14.5.156/ acymbor/cmsmadesimple$1.3 /$.

17. Biblioteka Szkoły Wyższej Psychologii Społecznej w Warszawie, „Szkolenie biblioteczne" na platformie e-learningowej: http://www.swps.pl/index.php/warszawa-biblioteka-szkolenie-biblioteczne.html.

18. Biblioteka Uniwersytecka w Białymstoku, „Szkolenie biblioteczne on-line": http://bg.uwb.edu.pl/szkolenie/index.php.

19. Biblioteka Uniwersytecka w Olsztynie, „Szkolenie biblioteczne on-line”: http://bart.uwm.edu.pl/bibgw/pl/index.php?ct=przysposobienie.

20. Biblioteka Uniwersytecka w Toruniu, „Przewodnik dla czytelników”: http://www.bu.umk.pl/przewodnik.html.

21. Biblioteka Uniwersytecka w Warszawie, „Szkolenie na platformie e-learningowej": http://moodle.come.uw.edu.pl/course/category.php?id=14.

22. Biblioteka Uniwersytecka w Zielonej Górze, „Przewodnik po bibliotece”: http://www.bu.uz.zgora.pl/bu/PRZEWODNIK/Info.htm.

23. Biblioteka Uniwersytecka we Wrocławiu, „Platforma e-learningowa”: http://bucd2.bu.uni.wroc.pl/moodle/.

24. Biblioteka Uniwersytetu Gdańskiego, „Szkolenie biblioteczne on-line”: http://szkolenie.bg.univ.gda.pl/.

25. Biblioteka Uniwersytetu Kardynała Stefana Wyszyńskiego w Warszawie, 
„Szkolenie biblioteczne on-line": http://www.biblioteka.uksw.edu.pl// index.php?option=com_content\&task=view\&id=55\&Itemid=87.

26. Biblioteka Uniwersytetu Łódzkiego, „Szkolenie on-line”: http://www.lib. uni.lodz.pl/library/szkolenie/informatorium.html.

27. Biblioteka Uniwersytetu Marii Curie-Skłodowskiej w Lublinie, „Szkolenie biblioteczne on-line": http://www.biblioteka.kampus.umcs.lublin.pl/ moodle/.

28. Biblioteka Uniwersytetu Medycznego w Lublinie, „Szkolenie biblioteczne": http://www.bg.umlub.pl/szkolenie/.

29. Biblioteka Uniwersytetu Medycznego w Łodzi, „Szkolenie on-line”: http://www.bg.umed.lodz.pl/index.php?option=com_content\&task=view\&id=82\&Itemid $=43$.

30. Biblioteka Wyższej Szkoły Bankowej w Gdańsku, „Szkolenie on-line”: http://www.wsb.gda.pl/wwwGdansk/bibliotekaGda_biblioteka.xml.

31. Biblioteka Wyższej Szkoły Bankowej w Toruniu, „Szkolenie biblioteczne on-line": http://www.wsb.torun.pl/wwwTorun/3064935.xml.

32. Biblioteka Wyższej Szkoły Bankowej w Toruniu, Wydział Zamiejscowy w Bydgoszczy: „Szkolenie biblioteczne on-line”: http://www.wsb.bydgoszcz.pl/wwwBydgoszcz/3124118.xml.

33. Biblioteka Wyższej Szkoły Finansów i Zarządzania w Białymstoku, „Szkolenie biblioteczne" na platformie e-learningowej: http://estudia.wsfiz. edu.pl/moodle/.

34. Biblioteka Wyższej Szkoły Humanistyczno-Ekonomicznej w Zamościu, „Szkolenie biblioteczne” na platformie e-learningowej: http:// www.wshe.zamosc.pl/index.php?option=com_content\&task=view\&i$\mathrm{d}=135$ \& Itemid $=69$.

35. Biblioteka Wyższej Szkoły Humanitas w Sosnowcu, „Szkolenie biblioteczne": http://www.humanitas.edu.pl/biblioteka/index.htm.

36. Biblioteka Wyższej Szkoły Turystyki i Hotelarstwa w Gdańsku, „Szkolenie biblioteczne": http://www.wstih.edu.pl/pliki/biblioteka/szkolenie_ biblioteczne.ppt.

37. Biblioteka Wyższej Szkoły Umiejętności Społecznych w Poznaniu, „Szkolenie biblioteczne": http://lib.amu.edu.pl/poczatkujacy/.

38. Biblioteka Wyższej Szkoły Zarządzania Ochroną Pracy, „Biblioteczne ABC": http://studia.wszop.edu.pl/index.php?s=2092. 


\section{Creators of on-line library trainings in Polish college libraries}

Abstract

On-line library training enables to enhance the teaching offer and makes the library resources more attractive; however, preparation of on-line training requires the librarians to have proper experience, knowledge and skills. The questionnaire's results presented in the article show what kind of education and skills the creators of on-line library trainings in Poland possess, and what is their work style. Moreover, there are opinions of responding librarians on the subject of efficiency of this new form of training. 